\title{
THE HISTORY OF THE COVID 19, AND ITS IMPACT ON THE CRUDE OIL PRICE CHANGES (IN CONTEXT OF INDIA`S COVID 19 CONTEXT)
}

\author{
Dr. Mohan Kumar K \\ Associate Professor of History, Government First Grade College Hosakote-562114
}

Article DOI: https://doi.org/10.36713/epra9304

DOI No: 10.36713/epra9304

\begin{abstract}
Oil is the most essential fuel for the world presently and the world, India is the third largest oil importer in the world, with 9.7 percent of the world oil imports, after China and USA, India imports around 80 percent of its oil needs and aims to bring down to 67 percent by 2022, by replacing it by local exploration, renewable energy and indigenous ethanol fuel, but in India there is lack of demand for crude oil and oil products due to Covid-19 epidemic, which made Indian government to imply restrictions, to lockdown of various firms, industries, public and private sector institutions, as health emergency, according to the report of IEA ( International Energy Agency) India's 40 days lockdown has led to decrease in 30 percent fall in countries demand for energy. Price inflexibility is concern for Indian oil producers, as it is the biggest shock since the Second World War, The global economy is expected to enter recessionary zone in 2020, as countries have shut down there normal business activities, to fight the pandemic led to imbalances in demand and supply of oil prices in the Indian market, Indian oil companies are waiting for the tax reductions and packages by the government, in the short term imbalance in oil demand and supply situation. The purpose of the research paper is that, Indian government has a great task to fight against pandemic as a health emergency and oil prices fluctuations in the year 2020.
\end{abstract}

KEY WORDS: History of the pandemic / covid social growth and crude oil prices (PETROLEUM),

\section{INTRODUCTION}

India's potential for production of petroleum products are not near to meet the petroleum need of the country's demand. Due to lack of oil resources India is dependent of these resources, after LPG (liberalisation, privatisation and globalisation) there was increase in demand for oil resources like petrol in various sectors, industrial sector, transportation sector and even in primary sector as fuel for agricultural technical machines, pump sets etc supply for the need of petroleum, oil resources was imported from Arab nations.

After February 2020 there was sudden decrease in demand for oil and petroleum products, due to government lockdown in India this scenario has two faces that is we can decrease the imports at same time there is a no growth in the production sectors, so by giving priority for health sector, government earns large of its income from excise duties, more than $85 \%$ is coming from oil imports. But government revenue from the other sources have plummeted due to corona So government hiked the petroleum and diesel prices by 10 and 13 rupees respectively It is interesting to see whether government continues to reduce taxes for petroleum products after $2^{\text {nd }}$ stage of lockdown in India .It will be huge burden for the Indian economy if it continues in a longer run.

\section{REVIEW OF LITERATURE UC CDC Definition}

Pandemic refers to an epidemic that has spread over several countries or continents usually affecting a large number of people.

WHO -"A pandemic is the world wide spread of a new disease .An influenza pandemic occurs when a new influenza virus emerges and spread around the world and most of the people do not have immunity". 


\section{EPRA International Journal of Research and Development (IJRD)}

\section{NEED OF THE STUDY}

The need to understand the fiscal policies, packages, tax concessions given by the Government.

4 A comprehensive strategy addressing the impact of current oil price crisis, has put the

India`s commerce and economic loss in the country.

\section{STATEMENT OF THE PROBLEM}

Overall covid-19 has brought uncertainty over supply chain of oil producers and Economic loss for Indian economy .The uncertainty about future looms heavily in the mind of government and the oil suppliers. But the concerted action by the nation's flexibility and the economic policies will surely turn the tide.

\section{OBJECTIVES OF THE STUDY}

1 It affects GDP, tax ratio, national income and it generates income to the government.
2 To understand the energy needs of the Indian economy through crude oil.

3 To enable sustainable growth of production, distribution of oil resources and policies by the government.

\section{RESEARCH METHODOLOGY}

This research output is the outcome of an overview conducted on the impact of covid-19 on Oil prices in Indian economy, in the Indian context experimental approach .It uses secondary Data for analysis discussion with expert from part of the research work.

\section{$>$ Nature of study}

The study is mainly descriptive in nature; secondary data are used for the purposes of the study.

\section{$>$ Secondary data}

Secondary data was collected from websites various sources like websites, books, articles and journals.

\section{DATA ANALYSIS}

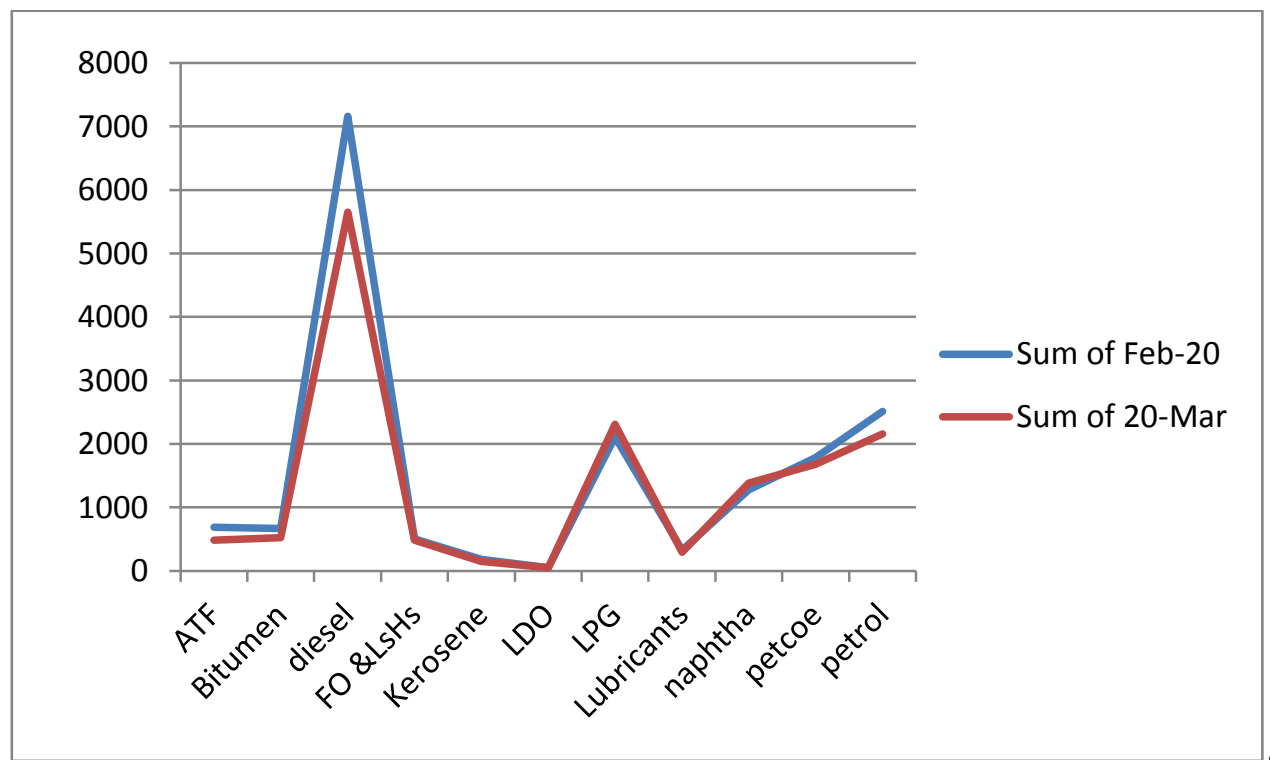

The image statistics data and table explains total fuel consumed in India, during pandemic situation, the government lockdown which shows negative effect on Indian Economy by decrease in demand for crude oil, petroleum products, in the months of February and March in 2020, where negative curve explains more percentage decrease in demand for the energy resources in Indian Economy due to Covid-19 situation.

\section{RESULT AND DISCUSIONS}

In the above figure signifies that covid-19 has severe impact on change in demand in crude oil, petroleum products in India, due to government lock down many sectors and firms implemented work from home option, stay home stay safe was the slogan given by many states in India, this was the main reason for decrease in demand for oil products in the months of February and March 2020, the other reason was increase in unemployment made citizens to spend less for fuel and energy sector, lockdown made transport sectors contribution almost nil, all these factors made decrease in demand for oil sector in Indian Economy. 


\section{EPRA International Journal of Research and Development (IJRD)}

\section{FINDINGS}

1 Covid-19 and its impacts have resulted in imbalances in production and supply for cured oil, petrol in the year 2020 in India.

2 Crude oil and petrol is very essential in India, as India is one of the leading importers of oil and petroleum products.

\section{IX.RECOMMENDATIONS/SUGGESITIONS}

1 Government role plays key factor in balancing essential oil resources, EXIM (Export and Import) policies.

2 India's crude oil sector strives to manage the uncertainties in short term in covid-19 lockdown, India needs to keep in perspective the longer term opportunities for growth in oil sector.

\section{CONCLUSION}

Indian economy is facing lot of constraints and challenges in 2020, due to covid-19 pandemic, Indian government 40 days lockdown has lead to around $30 \%$ decrease in demand for curd oil, according to the report of IEA (International Energy Agency). Indian economy has negative impact on covid-19 pandemic, oil prices are of great concern, due to imbalance in production and supply of crude oil, petroleum products. These imbalances may lead to negative growth in the oil and energy sectors contribution towards the economy. Covid-19 has already has its impact on price of crude oil and its trade. Combined effect of covid-19 and price was resulted in price of Brent crude oil reaching 17 years low. India has managed to control the crude oil prices till second stage of lockdown by variability in taxes, but in long run it is tuff ask for Indian economy to overcome health crisis due to covid-19 and flexible growth of crude oil production and supply .The purpose of the research paper is that how Indian economy can achieve stabilised energy growth during covid-19 pandemic situation by available resources in the Economy.

\footnotetext{
XI. LIMITATION

1 In long run these uncertainties may increase in unemployment in Indian economy and negative growth of oil production.

2 India's priority to improve health crisis has negative impact on oil resources demand in the economy.

3 Imbalance in trade in Indian economy may cause disequilibrium in balance of payment with external world.
}

\section{SCOPE OF THE STUDY}

Indian economy is one of the fastest developing economies in the world and has great demand for energy sources like crude oil. Industrial sector, Transportation, recently in agricultural sector also fuel like petrol, oil resources are used in technical tools and motors .India's oil resources are not sufficient to meet the demand of the country. So India's imports are more than $65 \%$ of oil resources externally. But covid-19 situation has made Indian economy to rethink and to produce crude oil, energy resources domestically or to be prepared for post covid-19 situation, because most of the economists are uncertain about the end of the pandemic situation. The scope of the study the importance of crude oil is to explain the need of reducing the crude oil imports in India and flexible balance of oil prices.

\section{REFERENCE}

1. https://unemploymentinindia.cmie.com/

2. Covid-19 challenge for Indian Economy Trade and Foreign Policy Effect

3. IEA (International Energy Agency)

4. CMIE (Centre for monitoring Indian economy), Bombay

5. EnergyWorld.com 